\title{
Effects of reactive phosphate rock and superphosphate on sheep and pasture production in hill country
}

\author{
S.F. LEDGARD ${ }^{1}$ and KR. JONES ${ }^{2}$ \\ ${ }^{1}$ Ruakura Agricultural Centre, MAF. Private Bag, Hamilton \\ ${ }^{2}$ Te Kuiti Research Area, MAF. PO Box 277, Te Kuiti
}

\begin{abstract}
Arad reactive phosphate rock (RPR) and single superphosphate(SSP) werecomparedasphosphate fertilisers in a sheep farmlet grazing trial and in two mowing trials over 3 years. The trials were on a volcanic ash soil at the MAF Te Kuiti Research Area on a site with limited fertiliser addition in the previous 2 years (Olsen $\mathrm{P}$ soil test averaged 10 in the grazing trial). Soil sulphur levels were high and there was no requirement for added sulphur over the -3 years of the trial. Pasture and animal measurements showed responses to SSP in all years, with RPR being initially less effective than SSP. By year 3, responses from RPR were near those from SSP. Economicassessmentof thegrazing trial corresponded with production data, except in year 1 when there was little benefit from either fertiliser. SSP was more cost-effective than RPR in year2 whereas they were similarin year 3 . Over the 3 years, both fertilisers were profitable and there was an apparent cumulative net benefit from SSP over RPR. It was estimated that by year 4 the cumulative net benefit would be similar for both fertilisers or would be reversed in favour of RPR.
\end{abstract}

Keywords reactive phosphate rock, hill country, grazing trial, superphosphate, mowing trials

\section{Introduction}

Phosphorus $(\mathrm{P})$ fertiliseruse is important formaintaining long-term productivity of hill country pastures (Gillingham et al. 1990; Lambert et al. 1990; O'Connor et al. 1990). However, the decline in product prices in recent years has resulted in some farmers reducing or stopping application of $\mathrm{P}$ fertiliser, which is one of their main items of discretionary expenditure. Reactive phosphate rock (RPR) represents an opportunity for reducing the cost of applied $\mathrm{P}$ by up to about $35 \%$ compared with single superphosphate (SSP) which has been the dominant form of $\mathrm{P}$ fertiliser.

A range of mowing trials has shown that RPR can be as effective as SSP in maintaining pasture production, although an initial lag in RPR effectiveness was observed (e.g. Sinclair 1990). A recent evaluation (Mackay 1990) of these fertilisers using mowing procedures suggested that RPR was at least as effective as SSP under grazing but was initially less effective under mowing (with animals excluded).

This paper presents results from a farmlet trial evaluationof the effectiveness of RPR, with assessment of effects on sheep and pasture production over 3 years. It includes acomparison withmowing trials and an assessment of the relative economics of the fertilisers.

\section{Materials and Methods}

Site and soil

The farmlet grazing trial was on rolling to steep hill country at the MAF Te Kuiti Research Area, $20 \mathrm{~km}$ south of Te Kuiti. The soil was a yellow-brown loam derived from Mairoa ash and had an average $P$ retention test of 96\%. Average MAFsoil tests at the beginning of the trial for $\mathrm{pH}, \mathrm{P}$, potassium (K) and sulphur (S) were 5.8, 10,6 and 29 , respectively.The area had received limited $P$ fertiliser for 2 years before the trial started $(1 / 3$ of the paddocks in each farmlet had received $250 \mathrm{~kg}$ SSP/ha/ yr, while $2 / 3$ had received no fertiliser).

\section{Grazing trial}

The following 3 farmlets each comprised 6 (0.5 ha) paddocks:

1) No $P$ fertiliser (control)

2) $30 \mathrm{~kg} \mathrm{P} / \mathrm{ha} / \mathrm{yr}$ as RPR (av. $220 \mathrm{~kg} / \mathrm{ha}$ )

3) $30 \mathrm{~kg} \mathrm{P/ha/yr}$ as SSP (av. $345 \mathrm{~kg} / \mathrm{ha}$ ).

The RPR was Arad from Israel andcontained 14.2 to $14.4 \%$ total $\mathrm{P}$, with $30 \%$ soluble in $2 \%$ citric acid. SSP contained 9.1 to $9.5 \%$ total $\mathrm{P}$ at 86 to $90 \%$ citricsolubility. Fertilisers were applied by hand in mid April of each year, beginning in 1988. In April 1990, all paddocks received a basal dressing of $80 \mathrm{~kg} \mathrm{~K} / \mathrm{ha}$ and 40 $\mathrm{kg} \mathrm{S} / \mathrm{ha}$ (equivalent to that in SSP) as $\mathrm{KCI}$ or $\mathrm{K}_{2} \mathrm{SO}_{4}$. 
Each farmlet was stocked at 16 ewes/ha with separate mixed-age flocks of Coopworths and there was a $25 \%$ annual replacement rate (6 year olds with 3 yearolds). Farmlets were rotationally grazed, except over lambing when they were set-stocked.

Measurements included ewe and lamb liveweights at approximately monthly intervals, wool weights at shearing in May and November (November only in 1988). pasture cover assessed visually at weekly intervals, annual pasture composition measurements on 5 fixed transect lines in each paddock, and pasture production over set-stocking (using a cage-exclosure method). In year 3. the latter was measured over a shorter time period because of a change to a 'sheddingoff' system of lambing.

Treatment effects on pasture production under grazing were also measured in a sub-trial within a control paddock. This commenced one year after the grazing trial started and consisted of 4 replicates of the 3 main treatments detailed above. Plot size was $2 \mathrm{mx}$ $6 \mathrm{~m}$ and pasture production was measured using a cage-exclosure method (2 cages/plot).

The $\mathrm{S}$ responsiveness of the site was examined in a paddock which received RPR and which had the lowest MAF soil $S$ test $(20$ and $32 \mathrm{ppm}$ in the $0-75$ and $75-150 \mathrm{~mm}$ depths respectively). Five pairs of plots (8 x $1.5 \mathrm{~m}$ ) were located and 0 or $40 \mathrm{~kg} \mathrm{~S} / \mathrm{ha}$ as gypsum was applied twice annually. Pasture production was measured using a cage-exclosure method.

\section{Mowing trials}

Two sites of about $5^{\circ}$ slope adjacent to the grazing trial were selected and fenced off to exclude animals. The sites had soil P levels which were low (Olsen P 8) and low-moderate (Olsen P 11).

The main treatments used in both mowing trials were $0,15,30$ and $45 \mathrm{~kg} \mathrm{P} / \mathrm{ha} / \mathrm{yr}$ as Arad RPR (applied on a total P basis) or SSP (applied on a citric-soluble $\mathrm{P}$ basis), and there were 4 replicates. Plot size was $5 \mathrm{x}$ $1.5 \mathrm{~m}$ and basal dressings of $\mathrm{K}, \mathrm{S}$ and trace elements wereregularlyappliedasdeterminedbyplantanalysis.

Pasture production was measured by mowing, and $50 \%$ of clippings were returned to each plot.

\section{Results and Discussion}

\section{Mowing trials}

Both mowing trials showed significant responses to sdded $\mathrm{P}$ in all years with an increase in pasture yield up to45 $\mathrm{kg} \mathrm{P} / \mathrm{ha}$ as SSP (Figure 1). For SSP, these responses averaged 10,33 and $25 \%$ at the Olsen P 8 site and 8.30 and $21 \%$ at the Olsen P 11 site in years 1.2 and 3 respectively.TheaverageresponsefromSSPwasgreater than that from RPR at both sites $(\mathrm{P}<0.05$ in year 1 and $\mathrm{P}<0.01$ in year 2). By year 3 , there was no significant difference between SSP and RPR at the Olsen P 11 site but SSP produced more $(\mathrm{P}<0.05)$ than RPR at the Olsen $\mathrm{P} 8$ site. Thus, the relative agronomic effectiveness (RAE) of RPR compared with SSP improved over time and was higher for the moderate soil $\mathrm{P}$ site than the low soil $\mathrm{P}$ site. In years 1,2 and 3 the RAE was about 40,70 and $95 \%$ for the moderate $\mathrm{P}$ site and about 30,40 and $80 \%$ for the low P site.

The temporal changes in the relative responsiveness to RPR and SSP were similar to those obtained on a nearby site of low-medium P status (Olsen P 10) which was part of the MAF National Series of P trials (site 7, Smith et al. 1990).
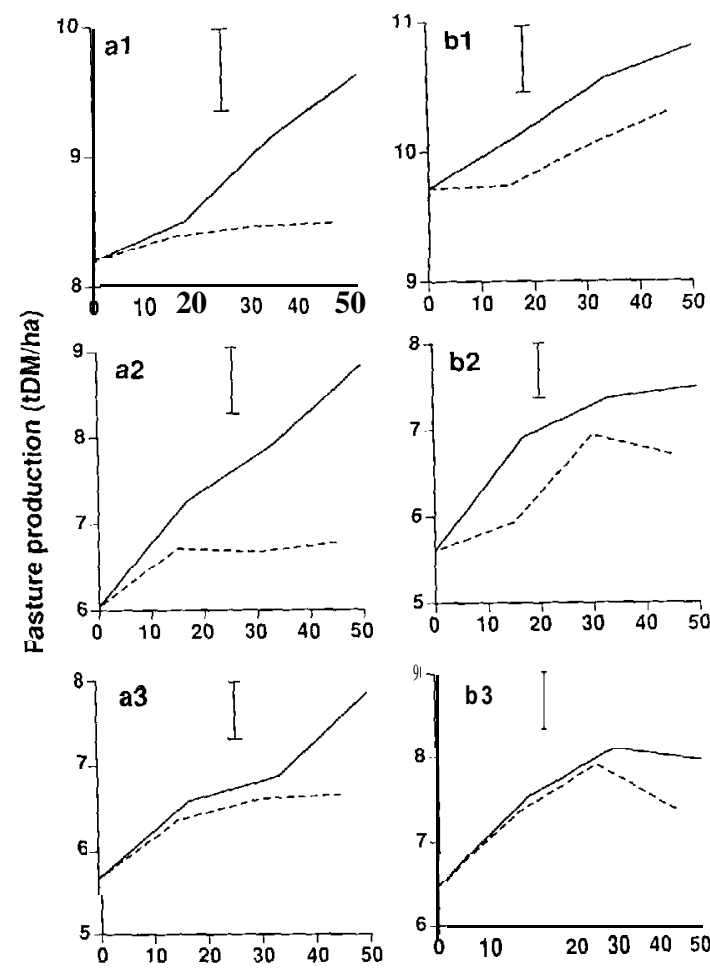

Total P applied ( $\mathrm{kg} / \mathrm{ha})$

Figure 1 Annual pasture production from varying rates of total $\mathrm{P}$ application as RPR (--) and SSP (- - ) in mowing trials on sites of (a) Olsen P 8 and (b) Olsen P 11. In the top left of each figure, the letter designates the site and the number designates year. Bars are LSD $(5 \%)$. 
Table 1 Effect of $P$ fertiliser on pasture production ( $\mathrm{kg} \mathrm{DM} / \mathrm{ha}$ ) from (a) all grazed paddocks during the set stocking period and (b) a grazed sub-trial within a control paddock (started in 1989).

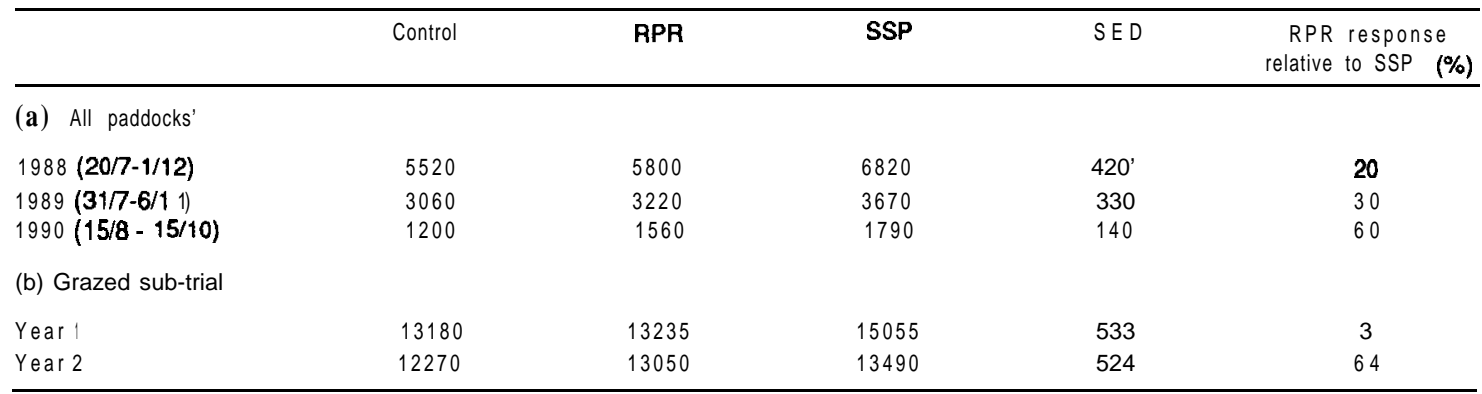

Year-to-year variations within a treatment were largely due to differences in period of measurement.

\section{Grazing trial}

\section{Pasture production}

Within all the grazed paddocks, pasture production measurements were limited to the August-November set-stocking period (Table 1). In year 1. SSP produced more $(P<0.05)$ than the control treatment. Data was more variable than in the mowing trials but showed similar trends between treatments and over time.

The sub-trial within a control paddock showed a significant response to SSP over the 2 years of measurement (Table 1). There was little response to RPR in year 1 but by year 2 the response from RPR was about two-thirds of that from SSP. Thus, there was a similar pattern of relative response from RPR and SSP under grazing and from the 2 mowing trials with shep excluded. This differs from the results of Mackay (1990) which indicated that RPR was more effective under grazing than under mowing.

The responsiveness to $\mathrm{S}$ was examined within the RPR paddock with the lowest soil $S$ test and revealed no significant effect of $\mathrm{S}$ application during the 3 years of the trial (data not presented).

\section{Pasture composition}

Fertilisers had no significant effect on pasture species composition except for an increase in ryegrass in the SSP treatment (Table 2). In the control paddocks, white dover tended to dedine whereas browntop and weeds tended to increase over the duration of the trial relative to the fertilised paddocks.

\section{Animal production}

Ewe liveweights in control and RPR flocks were similar during the first 12 months, while those in the SSP flock were up to $6 \%(P<0.05)$ higher in November
Table 2 Effect of $P$ fertiliser on pasture composition (\% frequency of occurrence in early spring; method described by Gillingham et al. 19901

\begin{tabular}{lccccc}
\hline Species & Year & Control & RPR & SSP & SED \\
\hline White Clover & 1988 & 27 & 29 & 28 & 4 \\
& 1989 & 40 & 41 & 50 & 7 \\
& 1990 & 14 & 20 & 24 & 6 \\
Ryegrass & 1988 & 63 & 64 & 68 & 7 \\
& 1989 & 44 & 44 & 57 & 5 \\
\multirow{2}{*}{ Browntop } & 1990 & 50 & 57 & 73 & 6 \\
& 1988 & 22 & $\mathbf{1 8}$ & 19 & 5 \\
\multirow{3}{*}{ Weeds } & 1989 & 36 & 27 & 32 & 8 \\
& 1990 & 32 & 23 & 24 & 7 \\
& 1988 & 58 & 51 & 53 & 6 \\
& 1989 & 45 & 45 & 36 & 5 \\
& 1990 & 61 & 48 & 45 & 8 \\
\hline
\end{tabular}

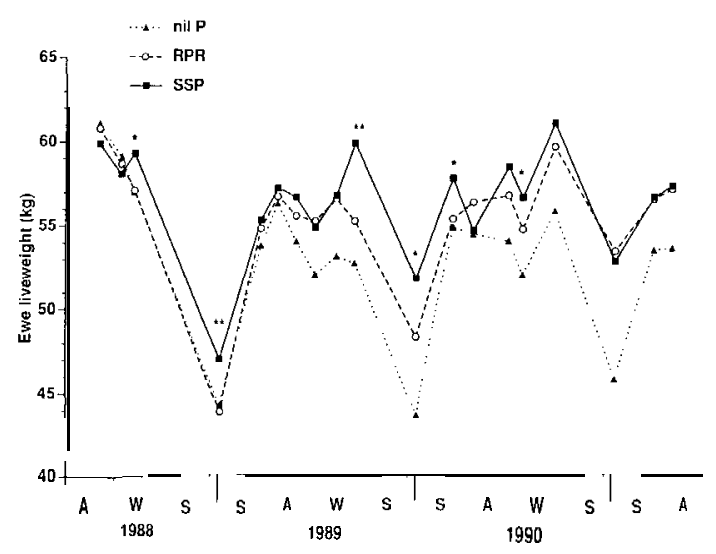

Figure 2 Average ewe liveweight from famlets treated with nil $P$ RPR and SSP. The average LSD (5\%) was 2.0 (range 1.8 to 2.6 ). Significant differences between $S S P$ and RPR areindicated by asterisks

1988 (Figure 2; Table 3). Although the SSP flock was significantly heavier than the RPR flock, strictlyspeaking this difference cannot be attributed to the 
Table 3 Effects of $P$ fertiliser on animal production

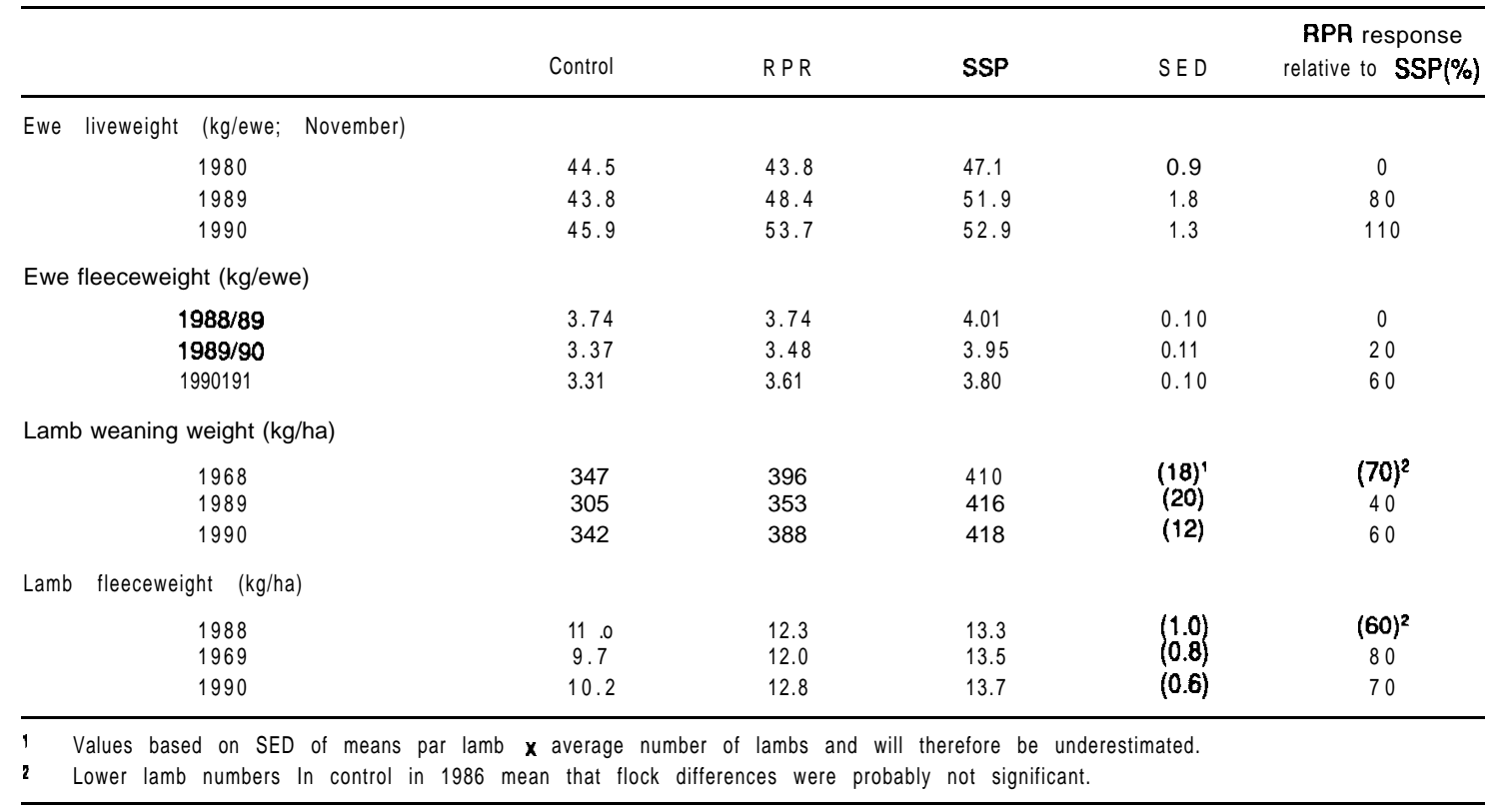

treatments because flocks were unreplicated. However, the ewes in each flock were not just restricted to one area but grazed 6 different paddocks thereby increasing the likelihood of the differences being due to the treatments.

In the second year, ewe liveweights in the control flock fell below those of the others. Flock differences were largest in winter and spring. By November 1989, ewes in the SSP flock were 18\% heavierthanthecontrol, while RPR ewes were intermediate. In the third year, ewe liveweights in the RPR flock approached those in the SSP flock. By November 1990, they were similar for the SSP and RPR flocks and were both up to $16 \%$ heavier than control ewes (Table 3). Sheep production from the control farmlet in year 3 was an overestimate because excessively low feed levels in late winter necessitated 'grazing-off' of ewes for 4 weeks.

Ewe fleece weights in the SSP flock were 7.17 and $15 \%$ higher than in the control flock in years 1.2 and 3 respectively. Fleece weights were lower $(\mathrm{P}<0.05)$ from the RPR flock than the SSP flock in years 1 and 2. However, the apparent response from RPR relative to that from SSP increased over time. Flock differences were larger for the November shearing than for the May shearing (Table 4). This corresponds with larger differences between treatments in feed availability during the winter-spring period, whereas pasture growth was more than sufficient for animal requirements during late spring/ summer.

Lamb data in Table 3 is presented on a per hectare basis to account for some variations in the number of
Table 4 Effect of $P$ fertiliser on ewe wool production ( $\mathrm{kg} /$ ewe) during two periods of the year.

\begin{tabular}{llllll}
\hline & Period of wool growth & Control & RPR & SSP & SED \\
\hline \multirow{2}{*}{1988} & May-Nov. & 1.34 & 1.31 & 1.38 & 0.06 \\
1989 & Dec.-April & 2.40 & 2.43 & 2.63 & $0.06 "$ \\
& May-Nov. & 1.20 & 1.32 & 1.66 & $0.08 "$ \\
1990 & Dec.-April & 2.17 & 2.16 & 2.29 & 0.06 \\
& May-Nov. & 1.33 & 1.48 & 1.66 & $0.06 "$ \\
1991 & Dec.-April & 1.98 & 2.13 & 2.14 & 0.07 \\
\hline
\end{tabular}

lambs between flocks. This was most evident in year 1 (18, 23 and 22 lambs/ ha in nil, RPR and SSP respectively) when flock differences also tended to be smallest, indicating that they were probably not significant. Apart from year 1, apparent trends in lamb weaning weights and wool weights were similar to those for ewe measurements.

Pasture production data from the mowing trials and from under grazing indicated that pasture growth was increased during the first year of the trial, at least from SSP addition. In general, this was less evident in lamb production, possibly because the effects of $P$ addition were initially being buffered by the ewes, as reported in another farmlet trial by Lambert et al. (1990).

By year 2, sheep production was less with RPR than SSP and by year 3 this difference had greatly diminished. Results from long-term mowing trials (Sinclair 1990) indicate that subsequent animal 
production may be similar for the 2 fertilisers, although it has been speculated that RPR could bemoreeffective than SSP in the long-term under grazing in hill country (Mackay et al. 1987).

Our results were obtained on a volcanic ash soil with amoderately high $\mathrm{pH}$ (5.8) which is similar to the average for other sheep and beef farms on ash soils in the Bay of Plenty (average pH 5.7) and in the whole of the North Island (average $\mathrm{pH}$ 5.8). based on the soil test summary of Ledgard et al. (1991). On soils of relatively low $\mathrm{pH}(<5.5)$ the rate of $\mathrm{P}$ release from RPR is faster than at higher $\mathrm{pH}$ and the 'lag' in Production from RPR is reduced (Rajan et al. 1991).

\section{Economics}

A crude economic assessment of sheep production from the farmlets of the grazing trial is given in Table 5. The relatively small increase in animal production from fertilisers in the first year was barely sufficient to cover the costs of applied fertiliser. In the second year, SSP was the most profitable option. By the third year, total returns tended to be highest from the SSP treatment but the difference in cost of fertilisers resulted in similar net returns per ha from the two $\mathrm{P}$ forms based on product prices applicable for April 1991. At higher product prices (e.g. applicable to 1990), the economic advantage from SSP appeared to continue into year 3 . Over the 3 years, the cumulative net benefit from fertiliser was small using April 1991 prices, but was much larger with 1990 prices. The cumulative net benefit tended to be higher for SSP than RPR, with the difference being larger for the 1990 prices.

Clearly, this economic assessment relates to our farmlet study and the relative economics of the $\mathrm{P}$ formsvaries withmany factorsof which twoimportant ones are (1) the responsiveness of the site, and (2) the returns from the farming enterprise. Other factors include the rate of $\mathrm{P}$ release from RPR (as affected by soil and climate at the site), the requirement for $S$ (which must be added to RPR if $S$ is required) and the relative prices of the $\mathrm{P}$ fertilisers.

An alternative approach for examining the economics of RPR relative to SSP was described by Chien $\boldsymbol{e t}$ al. (1990). This approach has the benefit of simplicity because it is independent of factors 1 and 2 above. It is based on comparing fertilisers at rates which give the same pasture production. Thus, it can be estimated from Figure 1 that the rates of total $\mathrm{P}$ as SSP that produced equivalent yields to $30 \mathrm{~kg} \mathrm{P} / \mathrm{ha}$ as RPR were about 11,13 and $20 \mathrm{~kg} \mathrm{P} /$ ha for years 1,2 and 3 at the low P site and 12, 15 and $28 \mathrm{~kg}$ P/ha for years 1,2 and 3 at the low-medium $P$ site respectively. An economic assessment using these values for the average of the 2 mowing trials is given in Table 6. It indicates that a lower rate of $\mathrm{P}$ as SSP could have been used in the first 2 years of the trial to obtain the same production as the RPR treatment. Economically, SSP would have been the most cost-effective in the first 2 years, whereas RPR was the most cost-effective in year 3 . Over the 3 years, there was a net cumulative benefit to SSP over RPR of $\$ 20 / \mathrm{ha}$ which was similar to that estimated from the grazing trial for April 1991 product prices (ca. $\$ 30 / \mathrm{ha}$ ), If production from RPR was similar

Table S Simple economic assessment of animal responses to RPR or SSP utilising approximate product prices for April 1991 (i.e. \$2.70/kg ewe

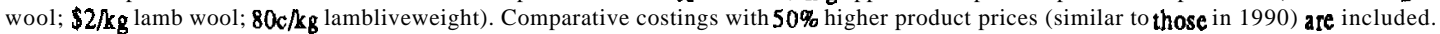

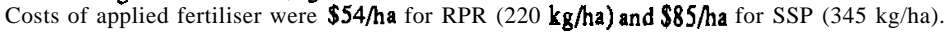

NB. Variability in data means that net returns an approximate and indicate trends only (LSD $5 \%$ for net returns is about $\$ 30 / \mathbf{h a} / \mathbf{y r}$ ).

\begin{tabular}{|c|c|c|c|c|c|c|c|c|c|c|}
\hline & & $\begin{array}{l}\text { Ewe } \\
\mathrm{kg} / \mathrm{ha}\end{array}$ & $\begin{array}{c}\text { wool } \\
\text { \$/ha }\end{array}$ & $\begin{array}{l}\text { Lamb } \\
\text { kglha }\end{array}$ & $\begin{array}{l}\text { wool } \\
\$ / \text { ha }\end{array}$ & $\begin{array}{l}\text { Lamb } \\
\mathrm{kg} / \mathrm{ha}\end{array}$ & $\begin{array}{c}\text { liveweight } \\
\$ / h a\end{array}$ & $\begin{array}{r}\text { Total } \\
\text { returns } \\
\mathbf{\$} / \text { ha }\end{array}$ & $\begin{array}{l}\text { Net } \\
\text { returns' } \\
\mathbf{\$} / \mathbf{h a}\end{array}$ & $\begin{array}{l}\text { Net returns } \\
(+\mathbf{5 0 \%} \text { product } \\
\text { prices } \mathbf{\$} \text { /ha }\end{array}$ \\
\hline \multicolumn{11}{|c|}{ Year 1: } \\
\hline & Nil $\mathbf{P}$ & 59 & 156 & 11 & 22 & 347 & 278 & 458 & 456 & 687 \\
\hline & R P R & 60 & 162 & 12 & 25 & 396 & 317 & 504 & 450 & 702 \\
\hline & SSP & 64 & 173 & 13 & 27 & 410 & 326 & 526 & 443 & 707 \\
\hline \multicolumn{11}{|l|}{ Year 2: } \\
\hline & Nil $\mathbf{P}$ & 54 & 146 & 10 & 19 & 305 & 244 & 409 & 409 & 614 \\
\hline & RPR & 56 & 150 & 12 & 24 & 353 & 262 & 455 & 401 & 629 \\
\hline & SSP & 64 & 172 & 14 & 27 & 416 & 333 & 532 & 447 & 713 \\
\hline \multicolumn{11}{|l|}{ Year 3: } \\
\hline & Nil $\boldsymbol{P}$ & 53 & 143 & 10 & 20 & 342 & 274 & 437 & $397^{2}$ & $616^{2}$ \\
\hline & RPR & 58 & 157 & 13 & 26 & 386 & 309 & 492 & $438(+30)^{3}$ & $664(+100)^{3}$ \\
\hline & SSP & 61 & 165 & 14 & 27 & 416 & 334 & 526 & $441(+60)$ & $704(+200)$ \\
\hline
\end{tabular}

Total returns minus fertiliser cost

Adjusted for cost of supplementary feed in late winter

Bracketed values are the cumulative net benefit from fertiliser use over the 3 year period. 
to that from SSP in year 4 (as found by Sinclair 1990). the net cumulative benefit over 4 years would be similar for the 2 fertilisers or would favour RPR.

Table 6 Economic assessment of RPR relative to SSP using rates of SSP to give equivalent pasture production to $30 \mathrm{~kg}$ P/ha as RPR (from Figure 1). averaged for the two mowing trials.

\begin{tabular}{|c|c|c|c|c|c|c|c|c|}
\hline & $\begin{array}{r}\mathrm{kg} \mathrm{P} / \mathrm{h} \\
\text { equiv. p } \\
\text { R P R }\end{array}$ & $\begin{array}{l}\text { a for } \\
\text { roduction } \\
\text { SSP }\end{array}$ & $\begin{array}{l}\text { \$ha t } \\
\text { RPR }\end{array}$ & $\begin{array}{l}\text { to apply } \\
\text { SSP to }\end{array}$ & $\begin{array}{l}\text { Net } \\
\text { SSP }\end{array}$ & $\begin{array}{l}\text { benefit } \\
(\$ / h a)\end{array}$ & & $\begin{array}{l}\text { Cumulative } \\
\text { net benefit } \\
\text { SSP (\$/ha) }\end{array}$ \\
\hline Year1 & 30 & 12 & 54 & 34 & & 20 & & 20 \\
\hline Year2 & 30 & 14 & 54 & 40 & & 14 & & 34 \\
\hline Year 3 & 30 & 24 & 54 & 66 & & -14 & & 20 \\
\hline
\end{tabular}

\section{Conclusions}

Trial results during the first 3 years showed:

1. The pasture response from RPR was less than that from SSP during the first 2 years but neared that from SSP in year 3.

2. Sheep production showed a similar pattern of response to that from pasture production.

3. Both fertilisers were profitable over 3 years.

4. The net economic benefit from SSP exceeded RPR in year 2 but was similar in year 3 .

5. Over 3 years, the cumulative net benefit from SSP tended to be higher than from RPR. Estimates for the fourth year suggest that this may be similar for both fertilisers or favour RPR.

\section{ACKNOWLEDGMENTS}

The valuable assistance of Barbara Dow, Biometrician, Ruakura is gratefully acknowledged. Also, we thank Nick Dodds for technical assistance and Mike Sprosen for analysis of mowing trial data.

\section{REFERENCES}

Chien, S.H.; Sale, P.W.G.; Friesen, D.K. 1990. A discussion of the methods for comparing the relative effectiveness of phosphate fertilizers varying in solubility. Fertilizer research 24: 149-157.

Gillingham. A.G.; Richardson, S.; Power, I.L.; Riley, J. 1990. Long term effects of withholding phosphate application on NorthIsland hill country: Whatawhata Research Centre. Proceedings of the NZ Grassland Association 51: 11-16.

Lambert, M.G.; Clark, D.A.; Mackay, A.D. 1990. Long term effects of withholding phosphate application on North Island hill country: Ballantrae.Proceedings of the NZ Grassland Association 51: 25-28.

Ledgard, S.F.; Johnston, T.J.M.; Edmeades, DC.; Wheeler, D.M. 1991. Soil nutrient status of the Bay of Plenty region and the implications to pasture productivity and fertiliser requirements. Proceedings of the NZ Grassland Association 53: 175-179.

Mackay, A.D. 1990. Comparison of superphosphate, partially acidulated phosphate rock, and reactive phosphate rock as phosphate fertilisers in a grazed hill country pasture and a traditional mowing trial. Proceedings of the NZ Grassland Association 51: 97-100.

O'Connor, M.B.; Smart, C.E.; Ledgard, S.F. 1990. Long term effects of withholding phosphate application on North Island hill country: Te Kuiti. Proceedings of the NZ Grassland Association 51: 2 1-24.

Rajan, S.S.S.; Fox, R.L.; Saunders, W.M.H.; Upsdell, M. 1991.Influence of $\mathrm{pH}$, time and rate of application on phosphate rock dissolution and availability to pastures. I. Agronomic benefits. Fertiliser research 28: 85-93.

Sinclair, A.G. 1990. Long term effectiveness of reactive phosphate rock as a phosphate fertiliser for New Zealand pastures. Proceedings of the NZ Grassland Association 51: 101-104.

Smith, L.C., Johnstone, P.D., Sinclair, A.G., Shannon, P.W., O'Connor, M.B., Percival, N., Roberts, A.H., Smith, R.G., Mansell, G., Morton, J.D., Nguyen, L., Dyson, C.B., Risk, W.H. 1990. Final report on the MAF 'National Series' forms of phosphate fertiliser trials. 1 Description of the trials and annual herbage dry matter production. MAF, Wellington. 